\title{
PENGARUH KUALITAS PRODUK DAN HARGA TERHADAP LOYALITAS KONSUMEN PADA PERCETAKAN UD. PRISMA JEMBER
}

\author{
SOVIA ANGGRAINI SETIONO \\ AHMAD HOLILI \\ Program Studi Ilmu Administrasi Bisnis \\ Sekolah Tinggi Ilmu Administrasi Pembangunan Jember
}

\begin{abstract}
ABSTRAK
Penelitian ini bertujuan untuk mengetahui pengaruh kualitas produk dan harga terhadap loyalitas konsumen. Penelitian ini dilakukan di Percetakan UD. PRISMA Jember. Metode pengumpulan data pada penelitian ini dengan kuesioner yang menggunakan teknik Sampling Jenuh, dengan sampel sebanyak 68 responden. Analisis yang digunakan dalam penelitian ini adalah analisis kuantitatif meliputi uji data dengan uji validitas, uji reabilitas dan uji asumsi klasik, analisis data dengan uji determinasi, uji koefisien dan ujikorelasi, lalu uji hipotesis dengan uji F dan uji t. Hasil penelitian ini menunjukkan bahwa secara simultan (uji F) nilai $F_{\text {hitung }}$ lebih besar dari nilai $F_{\text {tabel }}(9,132>3,14)$, dan nilai signifikansi (sig) = 0,000 yang lebih kecil dari nilai $\alpha=0,05$. Hasil ini menunjukkan bahwa secara simultan kualitas produk dan harga berpengaruh signifikan terhadap loyalitas konsumen. Secara parsial (uji t) kualitas produk menunjukan nilai $t_{\text {hitung }}$ lebih besar dari nilai $t_{\text {tabel }}(3,375>1.6675)$ dan nilai signifikasi $0,001<$ 0,05. Hasil ini menunjukkan bahwa secara parsial kualitas produk berpengaruh signifikan terhadap loyalitas konsumen. Serta harga menunjukkan nilai $t_{\text {hitung }}$ lebih besar dari nilai $t_{\text {tabel }}(1,749>1.6675)$ dan nilai signifikasi $0,005<0,05$. Hasil ini menunjukkan bahwa secara parsial harga berpengaruh signifikan terhadap loyalitas konsumen. Hasil analisis menggunakan uji determinasi diketahui bahwa 19,5\% variabel loyalitas konsumen dapat dipengaruhi oleh variasi dari variabel kualitas produk dan harga, sedangkan $80,5 \%$ dipengaruhi oleh variabel lain yang tidak diteliti dalam penelitian ini.
\end{abstract}

Kata Kunci: Kualitas Produk, Harga, Loyalitas Konsumen 


\section{PENDAHULUAN}

Dalam industri percetakan saat ini yang semakin kompetitif, loyalitas konsumen menjadi fokus utama dari setiap perusahaan untuk dapat meralisasikan secara berkelanjutan. Berbagai upaya kegiatan pemasaran telah banyak dilakukan untuk memuaskan konsumen, sehingga tidak jarang segala daya dan dana perusahaan digunakan untuk upaya pencapaian loyalitas konsumen. Perkembangan teknologi, globalisasi, dan terbukanya pasar dunia merupakan tantangan berat bagi perusahaan. Dengan terbukanya pasar dunia maka persaingan bisnis menjadi semakin tajam sehingga eksistensi perusahaan akan ditentukan oleh perusahaan yang paling efisien dan paling memuaskan konsumen, sedangkan perusahaan yang tidak siap bersaing akan tereliminasi dari pasar. Perusahaan harus menerapkan kebijakan dan strategi yang relevan dalam rangka persaingan bisnis yang semakin ketat. Salah satu strategi yang dapat diterapkan oleh perusahaan adalah menjaga retensi konsumen dengan menciptakan produk-produk yang handal, memiliki kualitas terbaik dan harga yang sesuai, sehingga akan menumbuhkan dan mempertahankan loyalitas konsumen.

Terdapat beberapa keuntungan strategik bagi perusahaan tentang pentingnya mempertahankan loyalitas konsumen."Imbalan dari loyalitas bersifat jangka panjang dan kumulatif. Jadi semakin lama loyalitas seorang konsumen, semakin besar laba yang dapat diperoleh perusahaan dari seorang konsumen" (Griffin,2002). Seorang konsumen yang loyal akan menjadi aset yang sangat bernilai bagi organisasi. Dipertahankannya konsumen yang loyal dapat mengurangi usaha mencari konsumen baru, memberikan umpan balik positif kepada organisasi. Sementara Kotler (2000) menyatakan bahwa"konsumen yang loyal (setia) merupakan peluang untuk mendapatkan konsumen baru. Mempertahankan semua konsumen yang ada umumnya akan lebih menguntungkan dibandingkan dengan pergantian konsumen karena 
biaya untuk menarik konsumen baru bisa lima kali lipat dari biaya mempertahankan seorang konsumen yang sudah ada.'Dalam upaya meningkatkan loyalitas konsumen, pihak perusahaan harus senantiasa meningkatkan dan mempertahankan kepercayaan konsumen terhadap perusahaan.Oleh karena itu kini banyak perusahaan yang berupaya untuk mengembangkan strategi yang efektif guna membangun, mempertahankan dan meningkatkan loyalitas konsumennya.

Percetakan UD. PRISMA didirikan pada tanggal 9 September 1994 di Jl. Otista 55 Mangli Jember oleh Bapak Drs. M. Fadlun.Percetakan UD. PRISMA adalah perusahaan yang bergerak di bidang jasa percetakan yang berupaya untuk memenuhi kebutuhan pelanggannya melalui penawaran seperti melayani Cetak kertas, Spanduk, Cetak perlengkapan sekolah, Sablon dan lain-lain.

Dalam percetakan UD.PRISMA kualitas produk yang baik dan harga yang sesuai menjadi salah satu strategi yang digunakan untuk menjadikan konsumen selalu menggunakan

produk-produk

percetakan

UD.PRISMA

Jember.Beberapa

keunggulan

mengenai kualitas produk dan harga yang ditawarkan percetakan UD. PRISMA untuk menjadikan konsumen loyal, antara lain :

1. Terdapat banyak pilihan produk baik spesifikasi maupun model produk, berikut pilihan produk yang diproduksi oleh percetakan UD. PRISMA antara lain : undangan, brosur, kop amplop, kop surat, buku, etiket, kalender, kwitansi, sertifikat, nota, kartu nama, blanko, bloc note, majalah, banner, umbul-umbul, baliho, bendera, raport, bed lokasi, map ijazah, sampul raport, nama dada, kartu pelajar, sablon plastik dan sablon kaos, stempel flas, stempel biasa, vandel, papan nama, stiker, gantungan kunci.

2. Percetakan UD. PRISMA mempunyai kepala produksi yang sudah berpengalaman selama 10 tahun di bidang produksi percetakan dan juga bagian produksi yang cekatan dalam memproduksi produk sehingga dapat meminimalisir cacat 
(kerusakan) pada produk yang diproduksi percetakan UD. PRISMA.

3. Percetakan UD. PRISMA juga mempunyai bagian desain \& setting yang berpengalaman dan handal sehingga dengan mudah dapat memenuhi keinginan desain produk yang diinginkan oleh konsumen.

4. Percetakan UD. PRISMA mempunyai alat produksi yang sangat memadai dan karyawan yang berjumlah 11 orang pada bagian produksi sehingga waktu pengerjaan suatu produk akan lebih cepat.

5. Percetakan UD. PRISMA memberikan harga yang terjangkau dengan kualitas dan bahan baku yang baik.

Hal diatas dapat mempengaruhi loyalitas konsumen percetakan UD.PRISMA, dengan keunggulankeunggulan yang ditawarkan

\section{TINJAUAN PUSTAKA}

\subsection{Kualitas Produk}

Kotler dan Amstrong (2001) mengartikan "kualitas produk adalah kemampuan suatu produk untuk percetakan diharapkan konsumen dapat tertarik untuk memesan dan menggunakan produk-produk yang diproduksi percetakan tersebut.Oleh sebab itu percetakan UD. PRISMA dituntut berusaha untuk memberikan yang terbaik bagi para konsumennya dengan membuat produk yang berkualitas baik akan tetapi harga yang terjangkau agar konsumennya tidak berpindah ke percetakan lain. Karena, dengan memberikan produk yang berkualitas maka tidak akan membuat konsumen percetakn UD. PRISMA berkurang bahkan dapat bertambah. Hal ini dimaksudkan agar konsumen menjadi konsumen yang loyal terhadap produk yang dihasilkan sehingga konsumen melakukan pembelian secara berkelanjutan dan menjadi konsumen tetap. Maka hal ini dapat membuat percetakan UD.PRISMA menjadi lebih baik lagi dalam menjaga kualitas produknya.

melaksanakan fungsinya, sedangkan Fandi Tjiptono, (2000) menyatakan "Produk merupakan segala sesuatu yang dapat ditawarkan produsen 
untuk diperhatikan, diminta, dicari, dibeli, digunakan atau dikonsumsi pasar sebagai pemenuhan kebutuhan atau keinginan pasar yang bersangkutan".

John Sviokla seperti yang dikutip oleh Lupiyoadi (2001) mengemukakan bahwa kualitas suatu produk memiliki delapan dimensi pengukuran yang terdiri dari aspekaspek berikut:

a. Kinerja (Performance), kinerja disini merujuk pada karakter produk inti yang meliputi merek, atribut-atribut yang dapat diukur, dan aspek-aspek kinerja individu. Kinerja beberapa produk biasanya didasari oleh preferensi subjektif pelanggan yang pada dasarnya bersifat umum (universal).

b. Keragaman produk (Features), dapat berbentuk produk tambahan dari suatu produk inti yang dapat menambah nilai suatu produk. Features suatu produk biasanya diukur ecara subjektif oleh masing-masing individu (dalam hal ini konsumen) yang menunjukkan adanya perbedaan kualitas suatu produk. Dengan demikian perkembangan kualitas suatu produk menuntut karakter fleksibilitas agar dapat menyesuaikan diri dengan permintaan pasar.

c. Kehandalan (Reliability), dimensi ini berkaitan dengan timbulnya kemungkinan suatu produk mengalami keadaan tidak berfungsi (malfunction) pada suatu periode. Kehandalan suatu produk yang menandakan tingkat kualitas sangat berarti bagi konsumen dalam memilih produk. Hal ini menjadi semakin penting mengingat besarnya biaya penggantian dan pemeliharaan yang harus dikeluarkan apabila produk yang dianggap tidak reliable mengalami kerusakan.

d. Kesesuaian (Conformance), dimensi lain yang berhubungan dengan kualitas suatu barang adalah kesesuaian produk dengan standar dalam industrinya. Kesesuaian suatu produk dalam industri jasa diukur dari tingkat akurasi dan waktu penyelesaian termasuk juga perhitungan kesalahan yang terjadi, 
keterlambatan yang tidak dapat diantisipasi dan beberapa kesalahan lain.

e. Daya tahan/ketahanan (Durability), ukuran ketahanan suatu produk meliputi segi ekonomis maupun teknis. Secara teknis, ketahanan suatu produk didefinisikan sebagai sejumlah kegunaan yang diperoleh oleh seseorang sebelum mengalami penurunan kualitas. Secara ekonomis, ketahanan diartikan sebagai usia ekonomis suatu produk dilihat melalui jumlah kegunaan yang diperoleh sebelum terjadi kerusakan dan keputusan untuk mengganti produk.

f. Kemampuan pelayanan (Serviceability), kemampuan pelayanan bisa juga disebut dengan kecepatan, kompetensi, kegunaan, dan kemudahan produk untuk diperbaiki. Dimensi ini menunjukkan bahwa konsumen tidak hanya memperhatikan adanya penurunan kualitas produk tetapi juga waktu sebelum produk disimpan, penjadwalan pelayanan, proses komunikasi dengan staff, frekuensi pelayanan perbaikan akan kerusakan produk dan pelayanan lainnya. Variabelvariabel tersebut dapat merefleksikan adanya perbedaan standar perorangan mengenai pelayanan yang diterima. Dimana kemampuan pelayanan suatu produk tersebut menghasilkan kesimpulan akan kualitas produk yang dinilai secara subjektif oleh konsumen.

g. Estetika (Aesthetics), merupakan dimensi pengukuran yang paling subjektif. Estetika suatu produk dilihat melalui bagaimana suatu produk terdengar oleh konsumen, bagaimana tampak luar suatu produk, rasa, maupun bau. Jadi estetika jelas merupakan penilaian dan refleksi yang dirasakan oleh konsumen.

h. Kualitas yang dipersepsikan (Perceive quality), konsumen tidak selalu memiliki informasi yang lengkap mengenai atributatribut produk dan jasa. Namun demikian, biasanya konsumen memiliki informasi tentang produk secara tidak langsung, 
misalnya melalui merek, nama dan negara produsen. Ketahanan produk misalnya, dapat menjadi sangat kritis dalam pengukuran kualitas produk.

\subsection{Harga}

"Harga adalah sejumlah nilai yang ditukarkan konsumen dengan manfaat dari yang memiliki atau pengguna produk atau jasa yang nilainya ditetapkan oleh pembeli dan penjual melalui tawar-menawar, atau ditetapkan ditetapkan oleh penjual untuk satu harga yang sama terhadap pembeli" (Umar. 2002). Menurut Kotler dan Amstrong (2001) bahwa "harga merupakan sejumlah uang yang dibebankan atas suatu produk atau jasa, atau jumlah dari nilai yang ditukar konsumen atas manfaatmanfaat karena memiliki atau menggunakan produk atau jasa tersebut".

Menurut Fandy Tjiptono (2000:167) indikator harga adalah sebagai berikut:

a. Harga jual merupakan harga akhir yang ditetapkan produsen akan suatu produk setelah adanya perhitungan semua bahan baku dan biaya produksi.

b. Kesesuaian hargamerupakan tinggi rendahnya harga ditetapkan perusahaan sesuai dengan kualitas produk tersebut, sehingga konsumen akan mendapatkan manfaat yang seimbang dengan jumlah uang yang dikeluarkan.

c. Perbandingan harga, perbandingan mengenai harga yang ditetapkan perusahaan dengan perusahaan lain dengan produk yang sejenis atau subtitusi sehingga konsumen akan dapat menetapkan pilihannya terhadap beberapa alternatif produk tersebut.

\subsection{Loyalitas Konsumen} Menurut Griffin menyatakan bahwa "loyalitas adalah pembelian berulang yang dilakukan oleh beberapa unit pembuat keputusan". Konsumen yang setia adalah mereka yang sangat puas dengan produk tertentu sehingga mempunyai antusiasme untuk memperkenalkannya kepada siapapun yang mereka kenal. 
Selanjutnya, pada tahap berikutnya, konsumen yang loyal tersebut akan memperluas "kesetiaan" mereka kepada produk-produk lain buatan produsen yang sama. Pada akhirnya mereka adalah konsumen yang setia kepada produsen tertentu untuk selamanya.

Konsumen yang loyal merupakan asset tak ternilai bagi perusahaan, karena itu karakteristik dari konsumen yang loyal menurut Buchari (2007), antara lain sebagai berikut:

a. Pembelian ulangadalah suatu wujud perilaku individual pada suatu tempat dimana konsumen melakukan pembelian secara berulang di suatu tempat sebagai hasil evaluasi konsumen terhadap pengalaman konsumsi sebelumnya.

\section{METODE PENELITIAN}

Penelitian ini dilalukan di percetakan UD. PRISMA Jember. Data diambil dari data primer yang diperoleh dari kuesioner yang diisi oleh responden secara langsung yaitu konsumen yang memesan atau menggunakan produk percetakn b. Penolakan pesaingadalah suatu perilaku dari individu yag melakukan suatu tindakan untuk tidak menerima ajakan untuk melakukan suatu pembelian produk atau jasa lain.

c. Tidak terpengaruh terhadap daya tarik produk/jasa lain, perilaku ini merupakan perilaku individual yang menunjukkan tidak ada ketertarikan terhadap produk atau jasa yang ditawarkan.

d. Merekomendasi kepada orang lain, perilaku ini merupakan perilaku dari individu yang melakukan rekomendasi atau mengajak individu lain untuk melakukan suatu pembelian sebuah produk atau jasa.

lebih dari dua kali periode bulan Januari s/d Juni 2016. Pengambilan sampel dalam penelitian ini menggunakan teknik Sampling Jenuh yaitu menjadikan seluruh anggota populasi menjadi anggota sampel (Sugiyono, 2010).Sehingga sampel 
dalam penelitian ini adalah 68 responden.

Variabel yang di gunakan dalam penelitian ini meliputi variabel independen Kualitas Produk (X1) dengan indikator kehandalan, keragaman produk, kesesuaian, kemampuan pelayanan, estetika. Harga (X2) dengan indikator harga jual dan kesesuaian harga. Sedangkan variabel dependen yaitu Loyalitas Konsumen (Y) dengan indikator penolakan pesaing dan merekomendasikan kepada orang lain.

Data yang terkumpul

\section{HASIL PENELITIAN}

\subsection{Uji Validitas dan Reliabilitas}

a. Uji Validitas

Berdasarkan hasil uji validitas tersebut menyatakan bahwa $\mathrm{r}$ hitung $>\mathrm{r}$ tabel berarti item-item dari semua variabel adalah valid.

b. Uji Reliabilitas

Berdasarkan hasil uji reliabilitas bahwa seluruh variabel yang digunakan dalam penelitian ini, yang terdiri darivariabel kualitas produk, selanjutnya di lakukan analisis sehingga dapat ditarik kesimpulan yang sangat berguna bagi penelitian sebagai dasar untuk membuat kesimpulan. Metode analisis yang digunakan dalam penelitian ini dilakukan melalui berbagi uji antara lain (1) Uji data yang meliputi uji validitas, uji reabilitas dan uji asumsi klasik, (2) Analisis data meliputi uji determinasi, uji koefisien dan uji korelasi (3) uji hipotesis meliputi uji F dan uji t. Semua perhitungan dalam analisi data dilakukan dengan bantuan program SPSS 16.

harga dan loyalitas konsumen adalah reliabel, karena dari hasil pengujian diperoleh koefisien lebih besar cronbach alpha dari $\mathrm{r}_{\text {tabel. }}$

\subsection{Uji Asumsi Klasik}

a. Uji Normalitas

Berdasarkan hasil uji normalitas menunjukkan nilai Kolmogorov-Smirnov $Z$ adalah 1,357 dan nilai Asymp. Sig. sebesar 0,150 yang lebih besar 
dari tingkat signifikansi 0,05 .

Dari hasil tersebut, dapat disimpulkan bahwa data penelitian berdistribusi normal.

b. Uji Multikolinearitas Berdasarkan hasil uji multikolinearitas menunjukkan bahwa nilai Tolerance 0,944 pada semua variabel lebih dari 0,01 dan nilai Variance Inflation Faktor (VIF) 1,059, pada semua variabel kurang dari 10,0 maka dapat disimpulkan bahwa tidak ada multikolinieritas antar variabel independen dalam model regresi.

c. Uji Heteroskedastisitas

Berdasarkan hasil uji glejser dapat terlihat bahwa nilai signifikasi kedua variable yaitukualitas produk sebesar 0,429 dan harga sebesar 0,934 lebih besar > 0,05 maka kedua variabel tidak terjadi heteroskedastisitas.

\subsection{Koefisien Determinasi $\left(R^{2}\right)$}

Berdasarkan hasil perhitungan koefisien determinasi menunjukkan nilai adjusted $\mathrm{R}$ square $=0,195$. Hal ini berarti bahwa sebesar 19,5\% variasi naik turunnya loyalitas konsumen percetakan UD. PRISMA Jember dipengaruhi variabel kualitas produk dan variabel harga. Sedangkan sisanya sebesar $80,5 \%$ dipengaruhi oleh variabel lain yang tidak diteliti.

\subsection{Analisis Regresi Linier Berganda}

Berdasarkan hasil analisis, maka dapat diperoleh persamaan regresi sebagai berikut:

$$
\mathrm{Y}=1,333+0,185 \mathrm{X} 1+0,198
$$

$\mathrm{X} 2$

Berdasarkan persamaan tersebut, maka dapat dijelaskan sebagai berikut:

a. Konstanta (a) $=1,333$ bernilai positif menunjukkan pengaruh positif. Ini berarti apabila variabel kualitas produk dan harga mengalami peningkatan maka loyalitas konsumen akan mengalami peningkatan. Hal ini dikarenakan nilai konstanta bertanda positif.

b. Koefisien regresi variabel kualitas produk adalah sebesar 0,185. Koefisien regresi tersebut bertanda positif yang 
menunjukkan bahwa antara kualitas produk dan loyalitas konsumen terdapat hubungan yang searah, artinya jika ada peningkatan dalam kualitas produk maka loyalitas konsumen juga akan meningkat.

c. Koefisien regresi variabel harga adalah sebesar 0,198. Koefisien regresi tersebut bertanda positif yang menunjukkan bahwa antara harga dan loyalitas konsumen terdapat hubungan yang searah, artinya jika ada peningkatan dalam harga atau harga yang ditawarkan sesuai maka loyalitas konsumen juga akan meningkat.

\subsection{Uji Hipotesis}

a. Uji F

Tabel 1. Hasil Uji F

\begin{tabular}{|c|c|c|c|c|c|}
\hline \multicolumn{6}{|c|}{ ANOVA $^{b}$} \\
\hline Model & $\begin{array}{l}\text { Sum of } \\
\text { Squares }\end{array}$ & Df & $\begin{array}{l}\text { Mean } \\
\text { Square }\end{array}$ & $\mathrm{F}$ & Sig. \\
\hline 1 Regression & 10.667 & 2 & 5.334 & 9.132 & $.000^{\mathrm{a}}$ \\
\hline Residual & 37.965 & 65 & .584 & & \\
\hline Total & 48.632 & 67 & & & \\
\hline
\end{tabular}

Berdasarkan hasil analisa diperoleh F hitung sebesar 9,132 dengan tingkat signifikansi sebesar 0,000. Hal ini membuktikan bahwa $\mathrm{F}$ hitung $(9,132)$ yang lebih besar dari $\mathrm{F}$ tabel $(3,14)$, maka $\mathrm{H}_{1}$ diterima dan $\mathrm{H}_{0}$ ditolak, berarti dapat disimpulkan bahwa ada pengaruh signifikan antara Kualitas Produk dan Harga secara bersama-sama terhadap Loyalitas Konsumen. 
b. Uji t

Tabel 2. Hasil Uji t

\section{Coefficients $^{\mathrm{a}}$}

\begin{tabular}{|c|c|c|c|c|c|}
\hline \multirow[b]{2}{*}{ Model } & \multicolumn{2}{|c|}{$\begin{array}{l}\text { Unstandardized } \\
\text { Coefficients }\end{array}$} & \multirow{2}{*}{$\begin{array}{c}\begin{array}{c}\text { Standardized } \\
\text { Coefficients }\end{array} \\
\text { Beta }\end{array}$} & \multirow[b]{2}{*}{$\mathrm{t}$} & \multirow[b]{2}{*}{ Sig. } \\
\hline & B & $\begin{array}{l}\text { Std. } \\
\text { Error }\end{array}$ & & & \\
\hline 1 (Constant) & 1.333 & 1.002 & & 1.330 & .188 \\
\hline $\begin{array}{l}\text { Kualitas } \\
\text { produk }\end{array}$ & .185 & .055 & .381 & 3.375 & .001 \\
\hline Harga & .198 & .113 & .197 & 1.749 & .005 \\
\hline
\end{tabular}

1) Berdasarkan hasil

2) Berdasarkan hasil analisis, variabel kualitas produk mempunyai $t$ analisis, variabel hitung yakni $\quad 3,375$ dengan signifikasi $=$ 0,001. Jadi 3,375>1.6675 harga mempunyai $\mathrm{t}$ hitung yakni $\quad 1,749$ dengan signifikasi $=$ 0,005. Jadi atau nilai signifikasi $1,749>1.6675$ atau nilai $0,001<0,05$ maka $\mathrm{H}_{0}$ ditolak dan $\mathrm{H}_{2}$ diterima, dan dapat disimpulkan bahwa variabel kualitas produk berpengaruh signifikan terhadap loyalitas konsumen. signifikasi $0,005<0,05$ maka $\mathrm{H}_{0}$ ditolak dan $\mathrm{H}_{3}$ diterima, dan dapat disimpulkan bahwa variabel harga berpengaruh signifikan terhadap loyalitas konsumen.

\section{PEMBAHASAN}

Berdasarkan hasil hasil analisis uji F menunjukkan bahwa kualitas produk dan harga secara bersama- sama berpengaruh terhadap loyalitas konsumen. Hasil penelitian ini mendukung hasil penelitian 
terdahulu yang dikemukakan oleh

konsumen di Percetakan

penelitian Nurhayati (2011),

UD.PRISMA Jember.

Amryyanti, dkk, dan Utami (2015)

Berdasarkan hasil analisis uji t, yang menyatakan bahwa kualitas produk dan harga berpengaruh signifikan terhadap loyalitas konsumen. Dari hasil tersebut menunjukkan bahwa kualitas produk dan harga sangat penting untuk menjadikan konsumen loyal pada produk dari percetakan UD. PRISMA Jember, sebab dengan adanya kualitas produk dan harga yang sesuai maka konsumen akan merasa yakin untuk tetap loyal pada produk percetakan UD. PRISMA Jember karena produk mepunyai kehandalan, produknya yang beragan, desain yang sesuai, kemampuan pelayanan yang cepat dan tampilan yang menarik.Juga mengenai harga yang ditetapkan oleh percetak UD. PRISMA sudah sesuai dengan bahan baku produk dan manfaat produk. Maka dapat dinyatakan bahwa variabel independen yang meliputi kualitas produk, dan harga, secara simultan atau bersama-sama berpengaruh signifikan terhadap variabel loyalitas 
dengan kriteria sebagaimana yang diharapkan oleh konsumen, dimana dalam hal ini konsumen atau calon konsumen akan mengharapkan kehandalan produk, keragaman produk, kesesuaian produk, kemampuan pelayanan dan estetika yang baik.

Berdasarkan hasi analisis uji t, harga berpengaruh terhadap loyalitas konsumen. Hasil ini sama dengan penelitian terdahulu yang dikemukaan oleh penelitian Nurhayati (2011), Amryyanti, dkk, dan Utami (2015) yang menyatakan bahwa harga berpengaruh signifikan terhadap loyalitas konsumen. Hal tersebut menunjukkan bahwa harga yang sesuai akan menjadikan konsumen menjadi loyal pada produk dari percetakan UD. PRISMA Jember.Artinya indikatorindikator dari harga yang meliputi harga jual yaitu mengenai harga jual dan kesesuaian harga, memiliki pengaruh terhadap loyalitas

\section{KESIMPULAN}

Berdasarkan penelitian yang telah dilakukan tentang pengaruh kualitas produk dan harga terhadap konsumen pada produk percetakan UD. PRISMA Jember. Dengan demikian dapat disimpulkan bahwa harga yang ditetapkan perusahaan sudah sesuai dengan kriteria sebagaimana yang diharapkan oleh konsumen, dimana dalam hal ini konsumen atau calon konsumen akan mengharapkan harga sesuai dengan bahan baku dan mafaat produk.

Berdasarkan Nilai adjusted $\mathrm{R}$ square $=0,195$ menunjukkan besarnya kontribusi pengaruh variabel independen terhadap variabel dependen dalam sebuah model. Hasil perhitungan menunjukkan nilai adjusted $\mathrm{R}$ square $=0,195$. Hal ini berarti bahwa sebesar 19,5\% variasi naik turunnya loyalitas konsumen percetakan UD. PRISMA Jember dipengaruhi variabel kualitas produk dan variabel harga. Sedangkan sisanya sebesar $80,5 \%$ dipengaruhi oleh variabel lain yang tidak diteliti. loyalitas konsumen pada percetakan UD. PRISMA Jember, maka 
diperoleh kesimpulan sebagai berikut:

1. Pengujian dengan menggunakan uji F (simultan atau secara besama-sama) dapat dijelaskan bahwa dua variabel yaitu kualitas produk dan harga secara bersama-sama berpengaruh terhadap variabel loyalitas konsumen. Hal ini dibuktikan dengan F hitung sebesar 9,132.

2. Pengujian variabel kualitas produk (X1) mempunyai $\mathrm{t}$

\section{DAFTAR PUSTAKA}

Arikunto, Suharsimi. 2002. Prosedur Penelitian.Jakarta : Rineka Cipta.

Assael, H. 1998. Consumer Behavior and Marketing Action. 6th ed. Cincinatti, OH: South Western College Publishing.

Buchari Alma. 2007, Manajemen Pemasaran \& Pemasaran Jasa. Bandung: CV. Alfabeta.

Ghozali, Imam. 2006. Aplikasi Analisis Multivariate dengan program SPSS. Semarang: Badan. Penerbit Universitas Diponegoro.

Griffin, Jill. 2002. Customer loyalty. Jakarta: Erlangga.

Indriantoro dan Supomo, 2002.Metodologi Penelitian untuk Akuntansi danManajemen, cetakan kedua, BPFE Yogyakarta.

Kotler, Philip and Gary Armstrong. 2000. Manajemen Pemasaran: hitung yakni $3,375>1.6675$

dengan signifikasi $0,001<0,05$.

Hal ini dapat dinyatakan bahwa variabel kualitas produk berpengaruh signifikan terhadap loyalitas konsumen.

3. Pengujian variabel harga mempunyai t hitung yakni 1,749 $>1.6675$ atau nilai signifikasi $0,005<0,05$. Hal ini dapat dinyatakan bahwa variabel harga berpengaruh signifikan terhadap loyalitas konsumen.

Analisis,

Perencanaan,Implementasi dan Pengendalian, Edisi 6, Jilid 2, Jakarta: Erlangga.

Lupiyoadi, Rambat, Hamdani A. 2001. Manajemen Pemasaran Jasa. Jakarta: Salemba empat.

Lingga Purnama. 2002. Strategic

Marketing Plan. Jakarta: Gramedia Pustaka Utama

Ratih Hurriyati, 2010. Bauran Pemasaran Dan Loyalitas Konsumen. Bandung : Alfabeta Sugiyono. 2008. Metode Penelitian Pendidikan Pendekatan Kuantitatif, Kualitatif, dan R\&D. Bandung: Alfabeta

Suprapto J. 2001. Pengukuran Tingkat Kepuasan Pelanggan Untuk Menaikkan Pangsa Pasar. Jakarta: Rineke Cipta. Swasta, Basu $\&$ Irawan.2005.Manajemen 
Pemasaran

Modern.

Yogyakarta: Liberty.

Tjiptono, Fandy. 2000. Prinsipprinsip Total Quality Service. Yogyakarta: Andi Offset

Umar, Husein. 2002. "Riset Pemasaran dan Perilaku Konsumen". Jakarta: PT. Gramedia Pustaka Utama.

\section{Jurnal dan Skripsi:}

Hardiawan, Febra dan Imam Mahdi. 2005. "Faktor-Faktor yang Mempengaruhi Kesetiaan Konsumen terhadap Sebuah Merek Rokok (Studi pada Mahasiswa Fakultas Ekonomi Universitas Sebelas Maret Surakarta)". Fokus Manajerial, Vol. 3, No. 1. www.eresources.perpurnas.go.idDiund uh April 2016

Mabruroh. 2003. "Membangun kepuasan konsumen dan ak ses loyalitas". Benefit, Vol. 7 No. 2 , Desember 2003.www.libgen.org/scimag Diunduh April 2016

Mouren, Margaretha. 2004. "Studi mengenai loyalitas pelanggan pada divisi asuransi kumpulan AJP bumi Putra". Jurnal Sains Pemasaran Indonesia, Vol. iii, No. 3, halaman 289308.www.sciencedirect.com Diunduh April 2016
Novita Dian Utami. 2015. Pengaruh kualitas produk, kualitas pelayanan, harga dan tempat terhadap loyalitas pada rumah makan di Surabaya. urnal Ilmu dan Riset Manajemen Volume 4 , Nomor 5

https://ejournal.stiesia.ac.id/jir $\mathrm{m} /$ article/download/801 Diunduh April 2016

Risky Nurhayati. 2011. "Pengaruh Kualitas Produk Dan Harga Terhadap Loyalitas Konsumen (Studi pada Mahasiswa Universitas Pembangunan Nasional "Veteran" Yogyakarta Jurusan Ilmu Administrasi Bisnis angkatan 2009 pengguna Handphone Merek Nokia)" Universitas Pembangunan Nasional "Veteran" Yogyakarta. http://repository.upnyk.ac.id/12 17/1/SKRIPSI.pdf Diunduh April 2016

Ruth Amryyanti et.al."Pengaruh Kualitas Layanan, Produk, Dan Kewajaran Harga Terhadap Kepuasan Dan Loyalitas Konsumen Pada Lnc Skin Care Singaraja" Universitas Udayana.http://eprints.undip.ac $. \mathrm{id} / 44605 / 1 / 07$ Diunduh April 2016 